\title{
Utilization of Selected Solid Wastes Through Control Cultivation of Oyster Mushroom Pleurotus florida and its Mineral Analysis
}

\author{
Oinam Jennifer ${ }^{1 *}$, Laishram Joymati Devi ${ }^{2}$ \\ ${ }^{1}$ Research Scholar, Department of Zoology, CMJ University, Jorabad, India \\ ${ }^{2}$ Associate Professor, Department of Zoology, DM College of Science, Imphal, India \\ *Corresponding author: jennifertaree@gmail.com
}

\begin{abstract}
An attempt was made to find out the impact of the selected substrates on the yield parameters such as sporophore initiation, first flush, total yield, biological efficiency and mineral contents. Amongst the five selected substrates used, paddy straw gave the highest in yield, biological efficiency and first flush. Mineral contents show variation according to the substrate used as bedding material. It was found that maximum amount of Calcium was found in the sample cultivated on rice husk, Potassium on paddy straw, Iron on saw dust and Phosporus on mixed substrate used as bedding materials. Through mushroom cultivation, combating food shortage and protecting the environment is possible for the sustenance of the ecosystem.
\end{abstract}

Keywords: Bioconversion, Solid wastes, Pleurotus florida, Mineral analysis.

\section{Introduction}

Urbanisation leads to continuous decrease in arable land, the ultimate result being decline in agricultural productivity and sustainability of agro ecosystems. Mushroom cultivation can alleviate food shortage, improve diversification of agricultural production.

Mushrooms are found to possess the two basic abilities of biodegradation and bioaccumulation, for the bioremediation of wastes. Mushroom cultivation serves as the most efficient and economically viable biotechnology for the conversion of longcellulose wastes materials into high quality protein food (Dike et. al., 2011). And therefore mushroom farms may be use as disposal sites for agricultural wastes products.

Because of its flexible nature, the Pleurotus genus is more cultivated than any other mushroom species (Rosado et.al., 2002). Pleurotus species requires no arable land for production and the abundant agricultural wastes found countrywide offers opportunity for production, which in turn provides a more economical and environmentally friendly disposal system (Stamets, 2000, Philoppousis and Diamantopoulou,2001). Identification of suitable substrate material is critical for successful mushroom cultivation (Zadrazil and Kurtzman, 1982; Shah et.al., 2004). Mushrooms are a good source of protein, vitamins and minerals (Kimenju et.al., 2009).

The experiment was carried out at the P.G. Dept. of Zoology,
D. M. College of Science, Imphal, Manipur from March 2015 to July 2015 with the goal of assessing the mineral contents of the mushroom production from the selected solid wastes, which is an important method for the recycling of the agro-wastes, alleviating food shortage as well as income generation.

Pleurotus florida was cultivated on five selected solid wastes viz. Paddy straw, Rice husks, water hyacinth, Saw dust and a mixture of all the selected four substrates. The cultivation was carried out in polythene bags (containing 500gm paddy straw on dry weight basis per bag) using grain spawn as well as the mineral contents was estimated.

\section{Materials and Method}

Cultivation of the species, Pleurotus florida.

A. Materials

1. Mushroom Spawn

2. Paddy straw, rice husks, water hyacinth and saw dust for making bed substrates: $500 \mathrm{gm} / \mathrm{bag}$.

3. Perforated transparent polythene bags: $30 \mathrm{x} 40 \mathrm{~cm}$

4. Spawn:100gms/bag

5. Sprayer:1 litre capacity

6. Containers for sterilization.

7. Binding threads.

B. Methodology

1) Procedure of the experiment

a) Spawn preparation:

The primary innoculum was prepared from the fresh fruiting body of the mushroom through tissue culture method and was maintained and multiplied by sub culturing on sterilized PDA medium in petri dishes and test tubes. The spawn was prepared on coarse paddy grains. The grains were half boiled and filled in transparent polythene bags, which were then sterilized in an autoclave at $15 \mathrm{psi}$ for 30 minutes. The inoculation was made on the following day under aseptic conditions and incubated at room temperature till the grains were covered with white mycelial growth. 


\section{b) Substrate preparation:}

Pleurotus florida was grown on the selected substrates viz. paddy straw, rice husks, water hyacinth, saw dust and mixture of the four selected substrates. The substrate paddy straw was obtained from a nearby farmland, rice husk from a rice mill, saw dust from a saw mill and water hyacinth from a nearby pond.

\section{i) Soaking:}

The substrates were chopped into $6-8 \mathrm{~cm}$ pieces and soaked in fresh water separately for a minimum of 20 hours and a maximum of an overnight.

ii) Sterilization and spawning:

The substrates were boiled for at least 30 minutes and were let to cool down at room temperature and the excess water was strained. The substrates were then filled in the perforated polythene bags layer by layer sandwiching the spawn grain respectively. The open ends were then bound by the binding threads and kept at a temperature maintained at about $30^{\circ} \mathrm{C}$ and well protected from pests.

iii) Cropping and harvest:

After the spawn run has completed and the bags were fully impregnated with white mycelia, the polythene bags were removed carefully. The open blocks were kept on racks about $20 \mathrm{~cm}$ apart. Water was sprayed regularly to keep it moist. Within 3-4 days of the spawn run pin-heads were seen and within another 3-4 days' mushrooms were ready for harvest.

\section{Analysis for mineral contents of the mushroom harvested}

The mushroom harvested from the various substrates were analysed for four selected minerals viz. Potassium, Calcium, Iron and Phosphorus.

\section{1) Digestion}

To estimate the contents of Potassium, Calcium, Iron and Phosphorus in the mushroom sample, digestion of the sample was carried out using double acids (Per chloric acid and nitric acid in the ratio 1:3) 0.3 gms (approx.) of the sample was taken in a $100 \mathrm{ml}$ beaker and digested it with double acid for 2-3 hours till the solution is clear. The solution was then made upto 100 $\mathrm{ml}$ with distilled water and used for the estimation:

i) Potassium (K):

The potassium content of the sample was estimated using flame photometric method.

\section{ii) $\operatorname{Calcium}(\mathrm{Ca})$ :}

The estimation of the calcium in the sample was carried out by Varsanite method.

iii) $\operatorname{Iron}(\mathrm{Fe})$ :

The estimation of iron in the sample was carried out using phenanthroline method

iv) Phosphorus $(P)$ :

The phosphorus present in the sample was estimated by Spectrophotometer method.

(Molybdo vanadate Spectrophotometric method).

\section{Biological Efficiency}

The biological efficiency was calculated as a percentage of the yield of the fresh mushroom to the dry weight of the substrates.

\section{Results}

Table 1

Sporophore initiation period and first (in days) of Pleurotus florida

\begin{tabular}{|c|l|c|c|}
\hline S.no. & Substrates & $\begin{array}{c}\text { Sporophore initiation } \\
\text { (in days) }\end{array}$ & $\begin{array}{c}\text { First flush } \\
\text { (in days) }\end{array}$ \\
\hline 1. & Paddy straw & 16 & 21 \\
2. & Water hyacinth & 21 & 28 \\
3. & Rice Husk & 18 & 21 \\
4. & Saw dust & 23 & 30 \\
5. & Mixed substrate & 20 & 25 \\
\hline
\end{tabular}

Table 2

Total yield (in grams) of P.florida on different substrates in total number of days

\begin{tabular}{|c|l|c|c|}
\hline S.no. & Substrates & $\begin{array}{c}\text { Total number } \\
\text { of days taken }\end{array}$ & Total yield*(gm/500gm) \\
\hline 1. & Paddy straw & 42 & 398.78 \\
2. & Water hyacinth & 54 & 256.41 \\
3. & Rice Husk & 60 & 281.81 \\
4. & Saw dust & 66 & 170.62 \\
5. & Mixed substrate & 49 & 284.84 \\
\hline
\end{tabular}

Table 3

Yield and biological efficiency of $P$.florida grown on different substrates

\begin{tabular}{|c|l|l|l|}
\hline S.no. & Substrates & Total yield* (gm/500gm) & $\begin{array}{c}\text { Biological } \\
\text { efficiency (\%) }\end{array}$ \\
\hline 1. & Paddy straw & 398.78 & 79.75 \\
2. & Water & 256.41 & 64.10 \\
3. & hyacinth & 281.81 & 56.36 \\
4. & Rice Husk & 170.62 & 34.12 \\
5. & Saw dust & 284.84 & 71.21 \\
& Mixed & & \\
& substrate & & \\
\hline
\end{tabular}

Table 4

Yield and biological efficiency of P.florida grown on different substrates

\begin{tabular}{|c|l|c|c|}
\hline S.no. & Substrates & Total yield* (gm/500gm) & $\begin{array}{c}\text { Biological } \\
\text { efficiency(\%) }\end{array}$ \\
\hline 1. & Paddy straw & 398.78 & 79.75 \\
2. & Water hyacinth & 256.41 & 64.10 \\
3. & Rice Husk & 281.81 & 56.36 \\
4. & Saw dust & 170.62 & 34.12 \\
5. & Mixed substrate & 284.84 & 71.21 \\
\hline
\end{tabular}

Table 5

Mineral contents of Pleurotus florida cultivated on different substrates

\begin{tabular}{|c|l|c|c|c|c|}
\hline S.no. & Substrates & $\begin{array}{c}\text { Calcium } \\
(\mathbf{g m \%})\end{array}$ & $\begin{array}{c}\text { Potassium } \\
(\mathbf{g m} \%)\end{array}$ & $\begin{array}{c}\text { Iron } \\
(\mathbf{g m} \%)\end{array}$ & $\begin{array}{c}\text { Phosphorus } \\
(\mathbf{g m} \%)\end{array}$ \\
\hline 1. & Paddy straw & BDL & 0.11 & 0.85 & 0.13 \\
2. & Water & BDL & 0.09 & 0.39 & 0.24 \\
3. & hyacinth & 0.002 & 0.01 & 0.59 & 0.24 \\
4. & Rice husk & BDL & 0.21 & 1.14 & 0.31 \\
5. & Saw dust & BDL & 0.04 & 0.65 & 0.90 \\
& Mixed & & & & \\
& subatrate & & & & \\
\hline
\end{tabular}

Sporophore initiation period and first (in days) of Pleurotus florida:

Different substrates showed different period (in days) for sporophore initiation. A minimum period of 16 days was taken by paddy straw for sporophore initiation followed by rice husk 
(18 days), mixed subsrate (20 days), water hyacinth (21days) and a maximum period of 23 days was recorded in saw dust substrate.

Regarding the first flush, paddy straw and rice husk gave first flush in a minimum of 21 days followed by mixed substrate in 25 days, water hyacinth in 28 days and a maximum of 30 days by the saw dust substrate.

Total yield (in grams) of P.florida on different substrates in total number of days:

The order of efficiency of total production in 500 gms substrate is,

paddy straw $(398.78 \mathrm{gms} / 500 \mathrm{gms})>$ mixed substrate $(284.83 \mathrm{gms})>$ rice husk $(281.81 \mathrm{gms})>$ water hyacinth (256.41gms) > saw dust (170.62gms).

Yield and biological efficiency of P.florida grown on different substrates:

The order of biological efficiency is paddy straw $(79.75 \%)$ $>$ mixed substrate $(71.21 \%)>$ water hyacinth $(64.10 \%)>$ rice husk $(56.36 \%)>$ saw dust $(34.12 \%)$.

Mineral contents of Pleurotus florida cultivated on different substrates:

The order of mineral content is,

Calcium:

Rice husk $(0.002 \%)>$ paddy straw $(\mathrm{BDL})=$ Water hyacinth $(\mathrm{BDL})=$ Saw dust $(\mathrm{BDL})=$ mixed substrate $(\mathrm{BDL})$.

Potassium:

Saw dust $(0.21 \%)>$ paddy straw $(0.11 \%)>$ water hyacinth $(0.09 \%)>$ mixed substrate $(0.04 \%)>$ rice husk $(0.01 \%)$

Iron:

Saw dust $(1.14 \%)>$ paddy straw $(0.85 \%)>$ mixed substrate $(0.65 \%)>$ rice husk $(0.59 \%)>$ water hyacinth $(0.39 \%)$

Phosphorus:

Mixed substrate $(0.90 \%)>$ saw dust $(0.31 \%)>$ water hyacinth $(0.24 \%)>$ rice husk $(0.20 \%)>$ paddy straw $(0.13 \%)$

\section{Discussion}

Increasing population is creating a serious in food availability. So, popularizing mushroom and its cultivation as part and partial of everyday food is of paramount importance.

Cultivation of mushroom provides an economical and profitable enterprise which gives an ample scope for selfemployment using agricultural wastes. Apart from being nutritious food and its medicinal properties, mushroom cultivation provides an ecofriendly way of solid waste management.

Suitability of paddy straw as bed substrates for oyster mushroom cultivation was reported by Bano and Srivastav (1962) and Block et.al (1958). Zadrazil and Schneidereit (1972) too observed that rice husk can be successfully for the oyster mushroom cultivation. Pani and Mohanty (1998) also reported water hyacinth to be a suitable substrate for oyster mushroom cultivation. Sharma and Jandaik (1981) reported the use of mixed substrates as bedding material with the view that mixed substrate provide a more balanced supply of nutrients to the mushroom. These findings were found to be similar with the present work. Besides, other agro wastes such as saw dust, rice husk, maize cobs, coir pith etc., which are mostly burnt leading to waste of energy pollution of the environment, can be converted into food, feed and fuel by oyster mushroom cultivation, representing the only economically profitable biotechnological process for the bioconversion of wastes plants residues.

In the present study quick sporophore initiation was observed in the case of paddy straw followed by rice husk, mixed substrate, water hyacinth and least in saw dust. The reason being the dependence of the sporophore initiation upon the nature of substrates used as bedding material. Similar reason was stated by Zadrazil (1978). It was found that paddy straw gave the highest first flush followed by water hyacinth. Similar observations were found in the study of Bahram (1989), Jandaik (1989) and Marimuthu et.al.(1991). Superiority of the paddy straw as a subsrate was reported by several workers ( $\mathrm{Pal}$ and Thapa,1979; Bahram, 1989; Jandaik, 1989 and Marimuthu et.al., 1991). They also reported a maximum biological efficiency of P.florida grown on paddy straw, which was found similar to the results of the present study. The present study showed high level of Calcium on the sample grown on rice husk., potassium on paddy straw, Iron on saw dust and phosphorus on mixed substrate. The findings are in agreement with the study of Pandey and Ghosh, 1996 and also with Randive, 2012.

\section{Conclusion}

The highest yield, highest biological efficiency, maximum protein, carbohydrate and caloric value were recorded in the P.florida grown on paddy straw substrates while the least were seen in the case of saw dust grown P.florida. The types of substrate that are used for cultivation influence sporophore initiation, first flush in number of days and in weight, total yield, biological efficiency, nutritional contents such as minerals. To conclude, it can be said that mineral $(\mathrm{Ca}, \mathrm{K}, \mathrm{Fe}$ and $\mathrm{P}$ ) contents showed variation according to the chemical composition of the substrate used as bedding material.

\section{References}

[1] Bahram, H., 1989. Mushroom Journal, 9:97-100.

[2] Bano, Z and Srivastav, 1962. Studies on the cultivation of Pleurotus species, Food Science, 11:363-365.

[3] Block, S.S., Tsao, G. and Han, L., 1958. Production of mushrooms from saw dust. Journal of Agricultural and Food Chemistry,6: 923-927.

[4] Dike K. S., Amuneke E. H., and Ogbulie J. N., 2011.J Microbiol. Biotech.Res., 2011,1(3):1-4.

[5] Marimuthu, T., Krishnamoorthy, A.S. and Jayarajan, R., 1991. Glimpses of Mushroom Research in Tamil Nadu Agricultural University, Coimbatore, P. 63.

[6] Pal. J. and Thapa, C. D., 1979.Cultivation of Dhingri made easy, Indian Journal of Mushrooms, 5:7-20.

[7] Pani, B. K., and Mohanty, A. K., 1998. Utilization of water hyacinth as an alternative substrate for oyster mushroom cultivation, Crop Res., 15:294.

[8] Shah Z. A, A shraf M, \& Istiaq M., 2004. Comparative Study on Cultivation and Yield performance of Oyster Mushroom (Pleurotus ostreatus) on Different Substrates (Wheat Straw, Leaves, Saw dust). 
Pakistan Journal of Nutrition 3(3):158-160 Asian Networks for Scientific Information.

[9] Sharma, A. D., and Jandaik, C.L., 1981, Quality of paddy straw and its effect on spawn run and yield of Pleurotus sajor-caju, Indian Journal of Mushroom, pp. 84-87.

[10] Sonali D. Randive, 2012 Cultivation and study of growth of oyster mushroom on different agricultural wastes substrate and its nutrient analysis: Advances in Applied Science Research, 3(4):1938-1949.

[11] Zadrazil, F. and Schneidereit, M.,1972. Die Grudlagen for die Inkultumahme einer bisher nicth kultivierten Pleurotus Art, Der Champion, 12:25-32

[12] Zadrazil, F., 1978. Cultivation of Pleurotus. In the Biology and Cultivation of edible mushrooms, (ed. S.T. and W.A. Hayes), Academic Press, New York, pp. 251-256.

[13] Stamets, P.,2000. Growing Gourmet and Medicinal Mushrooms.A Companion Guide to the Mushroom Cultivation, $3^{\text {rd }}$ Edn., Ten Speed Press, California.
[14] Zadrazil, F. and R.H. Kurtzman, 1982. The Biology of Pleurotus Cultivation in the Tropics. In: Tropical Mushrooms: Biological Nature and Cultivation Method, Chang, S.T. and T.H. Quimio(Eds.). The Chinese University Press, Hong Kong, pp: 277-298.

[15] Philoppousis and Diamantopoulou,2001. Bioconversion of Agricultural lignocellulosic wastes through the cultivation of edible mushrooms Agrocybe aegerita, Volvacea and Pleurotus Spp. Worl J. Microbiol. Biotechnol., 17:191-200.

[16] Rosado, F. R., Carbonero, E. R, Kemmelmeier, C., Tischer, C. A, Gorin. P. A. J., Iacomini, M. A partially 3-0-methylated $(1 \rightarrow 4)$ linked a-dgalactan and a-d-mannan from Pleurotus ostreatoroseus Sing.FEMS Microbiology, vol. 212, pp. .261-265.2002.

[17] Kimenju, J. W., G. O. M. Odero, E.W. Wachira, R. D. Narla and W.M. Muiru,2009. Suitability of locally available substrates for oyster mushroom (Pleuritus ostreatus) cultivation in Kenya. Asian J. Plant Sci., 8:510-514. 